Instructions for authors, subscriptions and further details:

http://qre.hipatiapress.com

\title{
From the Minds of Adolescents: What Has Worked for Them in an Education Intervention in the Slums of Nairobi
}

Benta A. Abuya ${ }^{1} \&$ Nelson Muhia ${ }^{1}$

1) African Population and Health Research Center (APHRC), Kenya.

Date of publication: October $28^{\text {th }}, 2020$

Edition period: October 2020 - February 2021

To cite this article: Abuya, B., \& Muhia, N. (2020). From the Minds of Adolescents: What Has Worked for Them in an Education Intervention in the Slums of Nairobi. Qualitative Research in Education, 9(3), 248-272. doi:10.17583/qre.2020.5144

To link this article: http://dx.doi.org/10.17583/qre.2020.5144

\section{PLEASE SCROLL DOWN FOR ARTICLE}

The terms and conditions of use are related to the Open Journal System and to Creative Commons Attribution License (CC-BY). 


\section{From the Minds of Adolescents: What Has Worked for Them in an Education Intervention in the Slums of Nairobi}

Benta A. Abuya

African Population and

Health Research Center
Nelson Muhia

African Population and

Health Research Center

(Received: 04 February 2020; Accepted: 08 September 2020; Published: 28 October 2020)

\section{Abstract}

This paper highlights findings from the, 'Advancing learning outcomes for transformational change (A LOT-Change), whose goal was to increase efforts towards securing the future of children living in urban informal settlements. The intervention was implemented in Korogocho and Site 2 respectively. This paper looks at the narratives from girls, boys and their parents and seeks to answer the question, "From the minds of adolescents: What has worked for them in an education intervention in the slums of Nairobi. Qualitative data comes from the qualitative component of the endline evaluation study that was collected in July and August 2018, by the African Population and Health Research Center (APHRC). Findings from this study done by APHRC show that: scores in numeracy skills and literacy skills improved, improved selfconfidence, which enabled girls to model the way in their schools and communities. Aspirations for school and higher education improved as girls and boys wanted to go beyond primary school. Communication improved across the board girls and boys, together with their parents. Girls and boys gained the confidence to speak up due to the knowledge gained out of the motivational talks within the leadership component. Overall, this paper reinforces the importance of young people having a voice to speak up on programs that affect their lives.

Keywords: adolescents, learning outcomes, qualitative, urban, girls 


\section{Desde las Mentes de los}

\section{Adolescentes: Qué Ha Funcionado en una Intervención Educativa en los Barrios Bajos de Nairobi}

Benta A. Abuya

African Population and

Health Research Center
Nelson Muhia

African Population and

Health Research Center

(Recibido: 04 de febrero de 2020; Aceptado: 08 de septiembre de 2020; Publicado: 28 de octubre de 2020)

\section{Resumen}

En este documento se destacan las conclusiones del estudio "Advancing learning outcomes for transformational change (A LOT-Change)", cuyo objetivo era aumentar los esfuerzos para asegurar el futuro de los niños que viven en asentamientos urbanos informales. La intervención se llevó a cabo en Korogocho y en Site 2, respectivamente. En este documento se examinan las narraciones de las niñas, los niños y sus padres y se trata de responder a la pregunta "Desde la mente de los adolescentes": qué les ha funcionado en una intervención educativa en los barrios marginales de Nairobi. Los datos proceden del componente cualitativo del estudio de evaluación final que fue recopilado en julio y agosto de 2018 por el Centro Africano de Investigación sobre Población y Salud (APHRC). Las conclusiones de este estudio realizado por el APHRC muestran que: las puntuaciones en las habilidades numéricas y de alfabetización mejoraron. La confianza en sí mismos mejoró, lo que permitió a las niñas modelar el camino en sus escuelas y comunidades. Las aspiraciones para la escuela y la educación superior mejoraron, ya que las niñas y los niños querían ir más allá de la escuela primaria. La comunicación mejoró de forma generalizada entre las niñas y los niños, junto con sus padres. Las niñas y los niños ganaron confianza para hablar, debido a los conocimientos adquiridos en las charlas motivacionales dentro del componente de liderazgo. En general, se refuerza la importancia de que los jóvenes tengan voz para hablar sobre los programas que les afectan.

Palabras clave: adolescentes, resultados del aprendizaje, cualitativo, urbano, niñas 
Q

uality education enables young people to make rational choices and enhance opportunities in life (World Bank, 2003). For girls, and their countries benefits include: reduction in household poverty (UNESCO, 2012); smaller family sizes; delayed marriage; improvement in child health; and, improved economic status of women, their families and communities (Hervish \& Feldman-Jacobs, 2011). Quality education can be achieved if the adolescent girls and boys remain engaged in school (Holt et al., 2008). Holt et al. (2008) further contend that adolescents need to be emotionally, cognitively and behaviorally engaged with the learning as it happens within the school for their success. Yet, the period of adolescence is one where these young people go through multiple changes (Blum et al., 2012, 2014). For instance, socially adolescents nurture the skills and knowledge to enable transition into adulthood, define their role and place in their respective families and communities, renegotiate significant relationships, develop their foundational beliefs, and embrace the dominant social norms, which includes the gender norms in a community (Kohli et al., 2018; Patton et al., 2016). It is for this reason that researchers who work on issues of adolescents have focused on interventions to improve adolescent health and education, particularly in the low resourced settings in subSaharan Africa (SSA) (Kohli et al., 2018). The Urban informal settlements in Nairobi Kenya was one such low resourced setting where it was necessary to implement an education intervention, incorporating the reproductive health constructs to improve the education and health outcomes of adolescents (APHRC, 2002). For instance, research evidence from an African Population and Health Research Center (APHRC) longitudinal study in 2009-2010, showed that children from poor households within the informal settlements were less likely to transition to secondary schools. For example, about 52 percent of children in the bottom quartiles in terms of household wealth transitioned to secondary school as compared to about 61 percent in the top quintiles. The overall transition rate for pupils residing in the urban slums of Nairobi was 59 percent, compared to 88 percent for pupils in non-slums households. Furthermore, APHRC evidence shows that 47 percent of children in urban informal settlements in Kenya attend non-state primary schools which do not have the necessary equipment with most teachers not being well-trained (Ngware et al., 2013). Lack of equipment and inadequate trained teachers means that pupils in the slums often need 
reinforcement on their education through afterschool programs (Abuya et al., 2015; Rose-Clarke et al., 2019). Because of the nature of the slum setting, girls can be predisposed to negative social behaviors that may lead to early pregnancies and marriages. For example, according to a longitudinal study by (Okigbo et al., 2015) involving 1,927 adolescent girls aged 12 to 19 living in Nairobi's urban informal settlements of Site 1 and Site 2Site 2, revealed that 6 percent had experienced sexual debut. These challenges in terms of education and sexual and reproductive health made necessitated the need for the education interventions of which the "Advancing learning outcomes and transformational change (A LOT Change is one such intervention that was implemented in the urban informal settlements in Nairobi. This was an afterschool program in partnership with Miss Koch and UTena, targeting adolescent girls in the two urban slums in Nairobi implemented between 2016-2019. Unlike the pilot phase, also called (Phase I) of the project, the A LOT Change (Phase II) included boys, backed with the evidence that both girls and boys from poor and disadvantaged households seemed to be affected in a similar manner in terms of primary school completion and transition to secondary school. The intervention packages implemented as part of the A LOT Change Program was multifaceted and included: Afterschool support with homework in literacy and numeracy; mentorship in life-skills; mentorship in leadership; primary to secondary transition subsidy: and guidance and counselling of parents.

The goal of this paper was to examine from the minds of adolescents, what they perceive to have worked for them at the end of a three years of implementation of this education intervention. The rationale for looking at these findings from the minds of adolescents is that more often in trials and implementation research we often ignore groups who matter most, and these are usually the intended recipients of our work (Twersky et al., 2013). This is indeed the case for adolescents for whom a lot of programs are developed and evaluated across sub-Saharan Africa. According to (Twersky et al., 2013), by not seeking the beneficiary perspectives, and tapping into their experiences with programs, we lose insights into the beneficiaries' daily experiences with these programs for which they are the beneficiaries, and therefore most important. Beneficiary perspectives can be sought at the onset of a program, during the program's life and at the end of the program. In the case of this paper, we focus on the narratives of beneficiaries at the end of 
the program. This study presents the views of the beneficiaries on the A LOT Change program. The need of the papers was to enable the young people to amplify their voices - as experts at the "frontline" and as their own best promoters - within the urban informal settlements. The paper will provide an open forum for beneficiaries to spontaneously self-disclose and tell what elements of A LOT Change program worked well for them, to improve the chances of transition to secondary school, life-skills and leadership training.

\section{The A LOT Change Intervention}

The A LOT Change intervention and its evaluation component was from which the paper draws its data was nested in the Nairobi Urban Health Demographic System (NUHDSS). This longitudinal platform has been run in the two slums of Nairobi, Site 1 and Site 2, by APHRC since 2002. These two slums exhibit characteristics such as inadequate housing, high episodes of violence, inadequate basic infrastructure, high level of insecurity, poor health indicators and high unemployment rate (APHRC, 2002). The 'Advancing learning outcomes' study included adolescent boys, in addition to girls who had been part of the pilot study (GEC Phase 1). The qualitative component of the end line evaluation provides the data that is used for this paper.

\section{Components of the A LOT Change Intervention}

\section{After-school support with homework in literacy and numeracy}

Boys and girls are supported by mentors to complete their homework in literacy and numeracy. The mentors, drawn from the community also act as role models to the young people. These mentors have completed secondary education with a mean grade score of $\mathrm{C}+$ or above in their Form four examinations. The after-school homework sessions were held twice a week, for three weeks in any given month. One session for literacy, and the other session covers numeracy skills. Each session lasts at least one hour. Recommended primary school grades, 6, 7, and 8 numeracy and literacy textbooks are used for homework support and revision (Abuya et al., 2016). Examples of these books include: Spotlight Quick Revision English for grade 
6; Progressive Primary Maths grade 6; Spotlight Quick Revision Maths grade 7; and Spotlight Quick Revision English graded 7; and New Primary Mathematics.

\section{Life skills training}

Within this component, knowledge on soft skills is shared among adolescents to enable them overcome the challenges of growing up. This is also to help the young people become responsible adults. Some of the topics that adolescents are exposed to include values, self-awareness, self-esteem, drug and substance abuse, relationships, HIV/AIDS, effective communication, effective decision-making, career goals and sexual and reproductive health. The life skills training sessions are facilitated by mentors once every month for the duration of the program (Abuya et al., 2016).

\section{Leadership training}

This aspect of the program exposed the adolescents to leadership skills through in-house leadership training sessions which covered topics such as ethical leadership, teamwork, building professional and social relationships, communication, and public speaking. Six in-house sessions were conducted by community mentors on the leadership topics. The main tenet of this component was to provide young people with opportunities to develop, refine, and practice their skills. Apart from the in-house sessions, the intervention included talks by accomplished leaders which are held during the school holidays, and exposure visits which were held once a year. The leadership component is expected to empower young people to provide transformative leadership in their respective communities by providing them with education and soft skills (Abuya et al., 2016).

\section{Primary to secondary transition subsidy}

A subsidy is provided for new secondary grade 1 entrants in Site 1 and Site 2 who will have scored 250 marks out of 500 and above in the Kenya Certificate of Primary Education (KCPE) examination. The financial support was to subsidize the cost of joining the first grade of secondary school by an 
amount equal to $\$ 113$. This was to enable the parents to buy the some school essentials that girls and boys needed for school, in order to ensure that all who qualified made a transition to secondary school. Those who score highly are admitted to top performing highly competitive public secondary schools in Kenya, also referred to as National schools. These schools follow the annual school fee guideline set by the Ministry of Education charged at between Ksh. 9000/- and Ksh. 54000/- (Ministry of Education Science and Technology, 2015), depending on the category of school. Sometimes some of these costs may be inflated upwards by the school management thereby making parents not to be able to send their children to school in a slum environment where $33 \%$ of households live below the poverty line (Emina et al., 2011). Financial support in the form of subsidy is therefore essential to achieve the aim of improving transition to secondary school.

\section{Guidance and counseling of parents}

Parents of adolescent boys and girls aged between 12-19 years are counseled by community counselors and encouraged to provide support for the education and schooling of children. This counseling is to help parents find ways of supporting and cushioning those children who are at risk of not completing primary or secondary school, or not able to transit to secondary school. This component of the intervention enables parents and community leaders to: (i) support children's schooling; (ii) minimize the time children are engaged in household chores and child labor; (iii) support children with their studies at home; (iv) encourage their children to attend after-school homework sessions; (v) cooperate with the volunteers and mentors to help girls and boys; (vi) cooperate with the teachers to track boys' and girls' performance in school; and, (vii) participate in sensitization sessions with boys and girls.

\section{Materials, Data and Methods Used in Paper}

The qualitative data comes from a qualitative subsample of the end line evaluation of the A LOT Change Program, collected by APHRC. During the end line evaluation, information was sought from parents, adolescent girls and boys, community leaders, and from those who were involved in the 
implementation of the program. This paper uses data that comes from interviews with adolescent girls and boys, and their parents. In order to get to the sample, we used purposeful sampling, which enabled us to include into a study, participants who are information-rich cases who warranted an indepth study, and emphasizes an in-depth understanding of the phenomenon under study (Patton, 2002). Data was collected using semi-structured interview guides and focus group discussion protocols. For this paper, we collected data using dialogues and IDIs with the adolescent pupils, and focus group discussions (FGDs) with their parents. Therefore, we developed the pupils' interview guide, and the FGD protocols. Data was electronically recorded and then transcribed verbatim. A coding scheme was generated both inductively and deductively. Coding was aided by using the NVivo software and a coding report generated for interpretation. Analysis was done using matrices to further delve into the data by making comparisons and contrasts in regard to the perceptions of the various participants in the study (Miles \& Huberman, 1994). Two study tools were used to collect the data presented in this paper: The parents' focus group discussion guide, which was used to elicit parental perceptions around their role and that of the community towards the supporting education of their children. Moreover, it was to illuminate the challenges that affect education in the two urban informal settlements, while appreciating the benefits of the intervention to them and their children; and the expectations by parents about the impact of the intervention among pupils' in the community. The pupils' dialogue interview guide, which was used to understand the role of pupils and that of their parents and community towards their education. It also highlighted the education challenges the children encounter in their communities, as well as explore benefits and challenges of the intervention. Finally the dialogue interview guide also probed on the pupils' understanding and availability of role models in their communities, and their future aspirations. For this paper we use data from the pupil dialogues and parents FGDs to share narratives from their own perceptions what worked for them from the intervention.

\section{Analysis}

All the qualitative data for the end line evaluation, from where data for this paper comes from were tape recorded and transcribed verbatim by a 
professional transcriber into MS Word documents. A coding scheme was generated by the research team both inductively and deductively (Boyatzis, 1998; Crabtree \& Miller, 1999), and fed into NVivo software to make it easier to organize the data collected from the study participants at the endline evaluation of A LOT Change Program. The deductive codes were largely based on the research questions guiding the qualitative study and previous studies. Inductive codes were informed by thematic areas that emerged during coding. Deductive coding enabled us to generate codes for our study.

Moreover, a review of the interview transcripts allowed us to identify the inductive codes that emerged from the data. We did this by identifying those phrases in the transcribed data that were related to the perception of the adolescents on what has worked or how they benefitted from the intervention at the endline (Maxwell, 2004; Miles \& Huberman, 1994). The first reading of the transcripts enabled us to gain an in-depth understanding into the responses that were provided by the pupils, their parents and community members on what has worked for them in this expanded phase of the intervention. The responses for female and male beneficiaries, their parents, and community members were compared and the codes then grouped into thematic areas. These narratives were then grouped into a matrix format (Miles \& Huberman, 1994). The following main thematic areas emerged from the minds of adolescence as far as what has worked for them from the education intervention in the slums of Nairobi: the scores in literacy and numeracy improved; improved self-confidence; improved communication; improved aspirations for school and higher education; confidence to speak up because of motivational talks; and a greater realization of how parents should play their role.

\section{Results}

\section{Improved Scores in Numeracy and Literacy}

One of the benefits from the program from the perspectives of the pupils was improvement in numeracy and literacy as a result of the afterschool support. This was seen in the improvement in scores among pupils in both sites. More so, boys emphasized that, they had also improved in the constructs taught in Math, such as algebra, proportions and ratios. A male pupil explained: 
... The programme has helped me, I had problems in Algebra...But our teacher explained it nicely to us and we understood. The same for English, and the broken passage. ...we were taught and I understood (Male Pupil, Site 1, 10082018).

Another beneficiary adds:

The project has helped us. There are things I never used to understand. The teacher explains very fast. But at Miss Koch they explain slowly (Male Pupil, Site 1, 06082018).

In the female dialogues the narratives pointed to the existence of a negative attitude that had been driven by the belief that Math, and the passing of it was left for the boys. When the girls changed their attitude, some of them are now the role models and examples to others, demonstrating that Math is doable and girls can equally excel. A female pupil in female dialogues in Site 2 extrapolated:

...Initially, I used to have a bad attitude in mathematics and would wonder what it would help me with. I thought that mathematics wasn't for girls but for boys... Nowadays, I pass and the teacher even uses me as an example to encourage others to change their attitude in mathematics (Female Pupil, Site 2, 06082018).

Improved scores in numeracy was re-emphasized by fathers who had girls in the program, who felt that with time the scores of children-particularly girls improved in Math. This father with a girl in the program explains:

...She was poor in math but now she is good in math and more responsible...We give her freedom to study. She also watches a little bit of TV, just so that she as an open mind. I want her to go far so that tomorrow she helps me ...or Kenya in general. I think Miss Koch has benefitted me in many ways... (Fathers of Girls, Site 1, 26052018).

Meanwhile, some of the beneficiaries explained that what has worked for them is the inspiration that they received from mentors, which catapulted 
them to think differently about some of the subjects that they had earlier thought to be difficult. This negative attitude has been turned around by mentors who were persistent on advising the young people that if you have a negative attitude toward an idea, subject or person, nothing good can come out of it. This is what a male beneficiary in male pupil dialogues in Site 2 said:

I think this project has really inspired me, to focus on education, because before I joined it, I did not focus on education and I had a negative attitude toward English [Emphasis added]. When I joined here (meaning the mentorship center in Site 2) my mentor told me that if you have a negative attitude towards a subject, you will never succeed in it. You will never pass... you have to be a positive attitude towards English, in order to pass it...I started having a positive attitude towards it and now, I am passing. (Male Pupil, Site 2, 06082018).

To some of the beneficiaries, writing of composition which is a sub-set of literacy has improved. This was in addition to the improvements that these beneficiaries have recorded in Math. The beneficiaries attribute the success in composition writing to the passion that is shown by the mentors in taking them through aspects of composition writing. A female beneficiary in a female dialogue intimated:

For me Miss Koch has really helped me especially in writing composition. I was not that good but nowadays, I have improved... at least I am writing something... One thing I love about the mentors is that they are very passionate about helping you. They want to guide you on what you have not understood. They don't shout at you and tell you that it is your problem and you should keep on failing and that is why you don't pass in school. The teachers (in school) usually tell you that some thirteen and twenties were invented for some people here... (Female Pupil, Site 2, 10082018).

When probed for reasons why they think that literacy and numeracy worked for them, beneficiaries who are boys explained that the numbers in the mentoring sessions are manageable as they are few. Therefore the 
mentors are able to give individualized attention. In addition, the beneficiaries also felt that what worked for them was that the mentors were able to spend enough time explaining the constructs and ideas to them during the sessions. This is in contrast to the classroom environment where a large number of pupils in class makes it hard for the pupils to understand the concepts explained by teachers. A male pupil said:

The difference is that they take time to explain questions. Everyone seems to understand, because, we are few. In school, there are many people, like in our class we have 72 pupils. And, the teacher goes at a fast pace. Some people ask questions in class but they are not answered and so they don't understand (Male Pupil, Site 2, 06082018).

In addition to mentors taking time to explain concepts and constructs, girl intimated that within the school environment, many of their teachers are often in a hurry to finish the syllabus. However, the program worked for the girls because the mentors worked with them closely and showed them kindness. A female pupil attending the female dialogues extrapolated:

...it has really helped me most of all in Mathematics... when you are in class, the teacher comes and teaches for thirty five minutes. He is very tough, and he teaches very fast so that he can finish his whole subject and syllabus. But, you see Miss Koch will show you love... That is why you see many people in class say that they hate Mathematics because the teacher teaches and then leaves but doesn't ask whether someone has understood or not but Miss Koch will teach you until you understand [Emphasis added] (Female Pupil, Site 1, 10082018).

Pupil beneficiaries are of the consensus that the afterschool program has worked for them because at the mentoring centers there are no disruptions that shorten the homework support time as seen with teaching in schools. The noise is less, mentors are not on phones unlike the teachers in the schools and therefore the mentorship at the centers goes on for a reasonable period of time. 
...In school, it is 35 to 45 minutes. So the teacher will come and you will not learn in those 35 minutes. You will have disruptions, and, someone will be teased in class, there will be noise or the teacher can take the phone and call. So, you will only find that you learn for 25 or 20 minutes. So the time is little in school compared to Miss Koch... (Female Pupils, Site 1, 10082018).

\section{Improved Self Confidence}

From the qualitative narratives, self-confidence also improved among the pupils in the course of the intervention. This was very evident from the perception of the adolescent girls and boys. From the narratives, improvement in self-confidence seemed to have worked better among girls in both sites, where it was very explicitly described as one of the outstanding tenets of the program. Improvements in self-confidence led to girls' increased self-awareness, consequently leading to effective interaction with the rest of their classmates in their classrooms and within the community thereby enabling the mentors and their teachers to deliver on the mentorship and teaching respectively. Self-confidence enabled the girls to develop leadership attributes which led to some of them being appointed to leadership positions the schools. This I what a female beneficiary in a girl dialogue explains:

Life skills has really helped me. Before I joined Miss Koch life skills program, I didn't have that self-confidence. But when I joined Miss Koch, we learned life skills... where we were being told that there is nothing that you cannot do as a woman. That gave me the confidence and I can now speak in front of girls... Overtime, the self-confidence has helped me in both school, home and as we interact [Emphasis added].... In school in 2016, I was made the head girl of the school because of the confidence [Emphasis added], unlike before. In 2017, I was upgraded to the president [Emphasis added]... (Female Pupil, Site 1, 10082018).

Moreover, improved self-confidence also enabled the adolescents to feel confident to contribute in their respective classrooms and challenge what is right and wrong. Challenging what is right and wrong was a significant 
milestone for young pupils in Site 1 and Site 2. This is because teachers are seldom challenged even if they are saying something that is not right. The significance of the growing self-confidence among girls in Site 1 cannot be underscored. A girls' dialogue in Site 1 had this to say in regard to selfconfidence:

R7: When I joined Miss Koch I used to be very shy. I never used to be able to stand in front of a class. When I was called to do a sum on the black board, I couldn't but with time I started being confident, and now, I can stand in front of the class and answer a question. R4: It has helped me because when I was in class six, I couldn't raise my hand and tell the teacher that I didn't understand something. But now, I can stand and tell the teacher if he has done a mistake, or, if there is a place that I don't understand, or if he has calculated badly. (Female Pupils, Site 1, 10082018).

Similarly girls in Site 2 also explained that what had worked for them in the program is that through the program, they have been able to gain selfconfidence. A girl in Site 2 explained:

It really helps us when people give their life stories and they tell us the challenges... They tell us how they were able to overcome them. It has also helped me in that initially I was not able to stand in front of people and speak. But now, I can...I can do anything because I have high self-confidence... (Female pupil, Site 2, 06082018).

Similar sentiments were expressed by parents in regard to how the program has worked for pupils to improve the self confidence in the two sites where the implementation was taking place. The Parents concurred that before the onset of the program, their daughters were not able to stand in front of any audience and express themselves. Yet, after participation in the program they are better able to express themselves. A mother attending an FGD of mothers with girls in the program said:

Then, she never had the confidence to talk to people since she has a big body. Even when she went to the neighbors she would play with children who are younger than her like in class five. But now since 
she joined the project she is courageous and now she talks in front of people and she can even sing in the parade. She is now active, initially, she wouldn't even talk to people in the house. But now she has improved and can speak for herself, she can even play with other children, she is confident she can even tell you jokes... (FGD, Mothers of Daughters in the Program, Site 2, 25052018).

\section{Improved Communication}

Improved communication has been one of the key outcomes of the project. The narratives show that communication was more conspicuous in Site 2. According to the boys in the program, improved communication has enabled them to bond with their parents, especially fathers. This is what a male pupil attending dialogues in Site 2 had to say about communication:

...I didn't have a good relationship with my father. I could not tell him what was disturbing me in my heart. I could not, but after some months in the program, I now started getting courage. I now started talking to my dad, because my dad could ask me what you have been learning. He could take my book and ask me questions...I find it fantastic, and started sharing all I had with my both parents. So, the implementer has really helped me, it has bonded me, my father and mother... (Male Pupil, Site 2, 06082018).

To some of the male pupils, improved communication has led to bonding which in turn has led a lot of ease between the boys and their parents to talk about pubertal issues to their fathers. A male pupils extrapolates:

...we are able to bond and talk to each other... about some of the changes that I am going through in my body. I can tell him, he's a male and I am a male so we can communicate about the changes that are happening. Before talking to my dad, and, mum was not that easy because I thought once I say something it might be too terrible or silly. So, I didn't trust myself enough to talk to my parents, but once I went to the program we were able taught about self-esteem which is, believing in yourself, so, if there is something I require I can ask my dad...(Male Pupil, Site 2, 06082018). 
Parents also reiterated that what worked for their children who joined the A LOT Change program was improved communication between the children and the parents. This element of communication was very helpful to mothers, particularly those that had boys in the program. These parents got a chance to sit with their sons to talk, reinforced by the parental counselling sessions that instilled the virtue of parental-child communication skill.

\begin{abstract}
...I just wanted to add, and say, that for real this education has helped me because we had some kids who were just roaming around...the way we have been taught by at Miss Koch, for now one can sit with his child and you talk more about life, and also the importance of education... (FGD, Mothers of Boys, Site 1, 24052019).
\end{abstract}

Moreover, improved communication also led to the beneficiaries becoming good public speakers because of working with mentors in the program to practice their public speaking. This was so pronounced so that a few beneficiaries were able to get to the highest level of public speaking within the Kenya National Music Festival. This is a highly ranked public speaking competition among schools in Kenya. One of the pupils who was in the program won a medal at the regional completion. Hence the slogan from one of the boys in Site 2 making a claim that you can "fake it till you make it" That they have made it and they did not expect to have reached that far, before the onset of the program.

\title{
Confidence to Speak up Because of Motivational Talks
}

Closely linked to improved communication is the confidence to speak up among the adolescents. This is partly tied to improved confidence among the pupils and the knowledge that the adolescents gained in the motivational talks. This has thereby enabled the adolescents to speak up about what they needed in school, what they believed in and what they wanted to do. Also connected to this was the realization that because of the confidence levels gained, and the ability to speak up, even on those issues that they cared about, the adolescents soon realized that they are not limited by their contexts. This is what one of the boys from Site 2 says of the motivational talks and what he has gained: 
R3: Personally, these come from the motivational speakers, they normally encourage us [Emphasis added], they tell us, and it doesn't matter where you come from, what matters is where you're going. It doesn't matter what you have done in the past, what matters is what you will do in the future. They usually tell us that no matter what the situation is, no matter where you are, just keep working hard so that in the future you will know what matters to you, you will know what you need for you to achieve it...(Male Pupil, Site 2, 06082018).

The excerpts that the adolescents got from the motivational speaking, enabled the boys in particular to be encouraged and feel confident that they can succeed despite their context. In so doing, motivational speaking started trickling into the Site 2 community, where young boys are championing the motivation speaking to their peers within the community. A male pupil attending dialogues in Site 2 had this to say:

...I joined Utena, I had no one apart from my teachers, and I had no one to motivate me, no one to guide me through my learning. So, after joining Utena in 2016, we started going for the motivation talks, and the motivational speakers inspired us, told us their stories about how they faced difficulties and challenges.... So, I decided from the inspiration, I no longer waste my time, time wasted is never recovered, so I had to do what I could, work hard. And also, from their motivations, you can see there are some people also facing same challenges as I do, so I passed the motivations from the speakers now to my friends, so you find that I am also a motivational speaker (Male Pupil, Site 2, 06082018).

\section{Improved Aspirations in School for a Better Life in Future}

From the perceptions of the adolescents the project has improved their aspirations in life for a better life in future. The aspiration is sometimes determined by the context and the goals set by pupils and their respective families. In this case, the young adolescents aspired to perform well in school, and uplift their families out of the slums. A girl in a girls' only dialogue in Site 1 explained: 
...there is nothing that is impossible as long as you put focus. Despite the negativity and the background that you come from, you can make it. What motivates me more is helping those that cannot help themselves, those affected with disease ....also what motivated me is that my father passed on because there was no money for his surgery. So, I saw that for me to be in a better position to help other people who won't pass on like my father, maybe I should be a neurosurgeon... (Female pupil, Site 1, 10082018).

\section{Greater Realization of How Parents Should Play Their Role}

From the perspectives of the adolescent pupils, there emerged a greater realization around the parental role. That parents should not only have the traditional roles of paying school fees, and providing basics at home, but rather have an expanded role to be role models at home. For example, the boys in Site 1 felt that their mothers are their role models because of the vital information that mothers imparted to them in the process of bringing them up. This is what a boy attending male dialogues in Site 1 had to say:

I would wish to be like my mother who has taught me respect to women... before I did not have respect for ladies but she has showed me that ladies have the ability to help the community and also she is very hard working she makes sure that at least in a day we have something to eat... (Male Pupil, Site 1, 10082018).

For some of the boys in Site 2 slum, the parents' role as a role model is directly related to them being the closest family members. Their proximity in the households dictate that they should ordinarily be the one to give a sense of direction.

For the girls in Site 2, their perception was that mothers are unique in their lives as girls and for that reason they prefer the mothers to be their role models. Girls feel comfortable talking to their mothers about what is affecting their lives - in part because mothers do have a recollection of what they experienced as girls and therefore easier for them to relate to their daughters. Moreover, girls feel that there are only those things that can be 
told to mothers and not fathers from their end. A girl attending dialogues in Site 2 intimates:

My mum...she tells me everything that she has gone through and what she used to do when she was young (Female pupil, Site 2, 06082018).

In addition, the girls felt that fathers are more knowledgeable about the issues affecting the boys and therefore should be role models for the boys. A girl attending a dialogue in Site 2 explains:

The fathers know about boys. At times people prefer mothers because there are things that you should not be told by your father, you should be advised by your mother (Female pupil, Site 2, 06082018).

Some of the adolescents felt that there are times that they do not tell their parents things that they do need to know. This is because parents are judgmental and that they tell the children are immoral. A boy attending dialogues in Koch said:

My mom (referring to mother) says that it is immoral and when you speak to her she thinks you have started getting bad morals so I just tell my teacher (Male Pupil, Site 1).

\section{Discussion and Conclusion}

The objective of this paper was to establish the perceptions of girls and boys in regard to the education intervention-A LOT Change that is being implemented in the two urban informal settlements of Site 1 and Site 2 to improve their learning outcomes, leadership skills, and social behavior. One of the outstanding aspects of what worked for the adolescents was improvement in numeracy and literacy as a result of the afterschool support. Ideally, the afterschool support in numeracy and literacy program was aimed at supporting the pupils in the urban informal settlements, strengthen the literacy and numeracy constructs. Improvement in the scores happened in the two sites-Site 1 and Site 2, and particularly among the boys. This finding 
extends the work of (Holt et al., 2008), who posit that when young people are mentored, there is a likelihood that they may feel connected to aspects of the school environment like teachers. We think that this connection may then lend itself to better pupil scores in literacy and numeracy, even when the intervention is not at school level like in the case with the A LOT Change intervention. However, scholars in different studies agree that sometimes the effects of mentoring may not necessarily reflect in higher test scores, but rather could be the improvements that come with a basic understanding of the concepts being studied in school (Abuya et al., 2015). Moreover, this study finds that the beneficiaries-boys and girls - were inspired by the mentors to the extent of changing their attitudes towards a subject like numeracy. The mentors advised young people that having a negative attitude does not yield anything good. This finding mirrors what other scholars have found in the context of the west, where similar interventions have been implemented. Specifically that the relationships built with mentors is very important and is part and parcel of the vital successes that mentee pupils will receive from such an education intervention (Somers et al., 2016).

Another outstanding aspect of this program that worked for adolescents was improvements in their self-confidence. Self-confidence was an improved marker for girls in both Site 1 and Site 2, leading to girls' increased selfawareness. Consequently girls could interact with their classmates in school, the teachers and the mentors. This finding suggests that as a result of this intervention, girls were provided with a nurturing environment in which they drew the support of their peers in class, the teachers in school, and the mentors within the community where the intervention was being implemented. This support led to a motivated cohort of adolescents confident enough to transition to high school (Abuya et al., 2015; Somers et al., 2016). We presuppose that it was also due to this confidence that the adolescents were able to challenge what is right or wrong - a significant milestone for young pupils in Site 1 and Site 2.

Closely connected to self-confidence was the improved communication that continued to thrive between the adolescents and their parents. The narratives show that communication was more conspicuous in Site 2, a site that had an additional leadership component in A LOT Change program. This is similar to the findings of the pilot study, (GEC 1) where the study showed that communication improved between parents and their daughters who were 
in the program. In the pilot study, parents were able to speak with their daughters, respond to their issues, and to some extent, monitor, mentor and guide girls even in the absence of their children (Abuya et al., 2015). This study further showed that similar to what has been advanced by (Somers et al., 2016), girls and boys in this current study needed support from their parents in-order to succeed (Holt et al., 2008; Somers et al., 2016). Moreover, adolescent boys in the program were clear about what was working for them, which was the support from their parents, more so their mothers who they looked up to be their role models at home. That parents should not only have the traditional roles of paying school fees, and providing basics at home, but rather have an expanded role to be role models at home. For example, the boys in Site 1 felt that their mothers are their role models because of the vital information that mothers imparted to them in the process of bringing them up.

This paper also adds significant ideas to the literature in regard to the benefits of a community based mentoring program which is the effective use of community resources to better the lives of adolescent girls and boys. The mentors, the parents, and the volunteer counsellors are part and parcel of the Site 1 and Site 2 community, who can be called upon to work with young people outside school, in order to support the efforts of the teachers in school. This ensures that the community becomes the change maker in the lives of the adolescents, and therefore ensures sustainability. Moreover, community involvement ensures that all the community members have a vested interest on the mentoring programs, thereby providing some supervision at community level and reducing potential safety threats. This finding contrasts that of scholars (Hawkins-Komosa, 2010) who presuppose that community based mentoring have a reduced chance for supervision, thereby heightening safety concerns for mentees in community based programs.

Overall, this paper raises key implications for programs that have young people as beneficiaries. First, this paper reinforces the importance of young people having a voice to speak up on programs that affect their lives. Second that effective communication between parents and their children, have persisted throughout the program for the last six years. This has ensured that young people stay close to their parents so that parents can play their part not only as caregivers, but also as role models. Thirdly, from the narratives of these young people, the presence of mentors has been key for the 
improvements that worked for them in the program. That mentors were important in the lives of these young people cannot be down played. What remains to be seen is how these impacts can be sustained overtime.

\section{Acknowledgments}

We acknowledge the study participants who participated in the A LOT Change Program. We also thank all the Education and Youth Empowerment team members for their valuable contribution to the success of the program. We also are grateful to the implementing organizations in Site 1 and Site 2 communities. We also thank the anonymous donor for supporting the A LOT-Change program.

\section{Funding Information}

The A LOT Change program, whose qualitative evaluation findings are presented in this paper, was supported by the [Anonymous Donors] under Grant [number 5343].

\section{References}

Abuya, B., Ngware, M., Hungi, N., Mutisya, M., Mahuro, G., Nyariro, M., Muhia, N., \& Mambe, S. (2015). Community participation and after-school support to improve learning outcomes and transition to secondary school among disadvantaged girls: A case of informal urban settlements in Nairobi, Kenya. APHRC.

http://aphrc.org/publications/improving-learning-outcomes-andtransition-to-secondary-school-through-after-school-support-andcommunity-participation/

Abuya, B. A., Ngware, M. W., Hungi, N., Kitsao-Wekulo, P., Mutisya, M., Gichuhi, N., Njagi, J., \& Mambe, S. (2016). Advancing learning outcomes and leadership skills through community participation.

APHRC. www.aphrc.org

African Population and Health Research Center (APHRC) (2002). Population and health dynamics in Nairobi's informal settlements. APHRC. 
Blum, R. W., Astone, N. M., Decker, M. R., \& Mouli, V. C. (2014). A conceptual framework for early adolescence: a platform for research. International journal of adolescent medicine and health, 26(3), 321331. http://dx.doi.org/10.1515/ijamh-2013-0327

Blum, R. W., Bastos, F. I., Kabiru, C. W., \& Le, L. C. (2012). Adolescent health in the 21st century. The Lancet, 379(9826), 1567-1568. https://doi.org/10.1016/S0140-6736(12)60407-3

Boyatzis, R. E. (1998). Transforming qualitative information: Thematic analysis and code development. Sage.

Crabtree, B. F., \& Miller, W. L. (1999). Doing qualitative research. Sage. Emina, J., Beguy, D., Zulu, E. M., Ezeh, A. C., Muindi, K., Elung'ata, P., Otsola, J., \&. Yé, Y. (2011). Monitoring of health and demographic outcomes in poor urban settlements: evidence from the Nairobi Urban Health and Demographic Surveillance System. Journal of Urban Health: Bulletin of the New York Academy of Medicine, 88(Suppl. 2). http://dx.doi.org/10.1007/s11524-011-9594-1

Hawkins-Komosa, K. (2010). Best Practices in School-Based Mentoring Programs for Adolescents AU - Komosa-Hawkins, Karen. Child \& Youth Services, 31(3-4), 121-137. http://dx.doi.org/10.1080/0145935X.2009.524477

Hervish, A., \& Feldman-Jacobs, C. (2011). Who Speaks for Me? Ending Child Marriage. Population reference Bureau.

Holt, L. J., Bry, B. H., \& Johnson, V. L. (2008). Enhancing School Engagement in At-Risk, Urban Minority Adolescents Through a School-Based, Adult Mentoring Intervention AU - Holt, Laura J. Child \& Family Behavior Therapy, 30(4), 297-318. http://dx.doi.org/10.1080/07317100802482969

Kohli, A., Remy, M. M., Binkurhorhwa, A. K., Mitima, C. M., Mirindi, A. B., Mwinja, N. B., Banyewesize, J. H., Natkwinja, G. M., Perrin, N. A., \& Glass, N. (2018). Preventing risky behaviours among young adolescents in eastern Democratic Republic of Congo: A qualitative study. Global public health, 13(9), 1241-1253. http://dx.doi.org/10.1080/17441692.2017.1317009

Maxwell, J. A. (2004). Causal explanation, qualitative research, and scientific inquiry in education. Educational researcher, 33(2), 3-11. https://doi.org/10.3102/0013189X033002003. 
Miles, M. B., \& Huberman, A. M. (1994). Qualitative data analysis (2nd ed.). Sage.

Ministry of Education Science and Technology (2015). Fees guidelines for public secondary schools in Kenya. Republic of Kenya.

https://www.education.go.ke/index.php/downloads/file/173-feesguidelines-for-public-secondary-schools-in-kenya

Ngware, M. W., Abuya, B., Admassu, K., Mutisya, M., Musyoka, P., \& Oketch, M. (2013). Quality and access to education in urban informal settlements in Kenya. African Population and Health Research Center. http://aphrc.org/wp-content/uploads/2013/11/ERPIII-Report.pdf.

Okigbo, C. C., Kabiru, C. W., Mumah, J. N., Mojola, S. A., \& Beguy, D. (2015). Influence of parental factors on adolescents' transition to first sexual intercourse in Nairobi, Kenya: a longitudinal study.

Reproductive health, 12, 73-73. http://dx.doi.org/10.1186/s12978015-0069-9

Patton, G. C., Sawyer, S. M., Santelli, J. S., Ross, D. A., Afifi, R., Allen, N. B., Arora, M., Azzopardi, P., Baldwin, W., Bonell, C., Kakuma, R., Kennedy, E., Mahon, J., McGovern, T., Mokdad, A. H., Patel, V., Petroni, S., Reavley, N., Taiwo, K., Waldfogel, J., Wickremarathne, D., Barroso, C., Bhutta, Z., O Fatusi, A., Mattoo, A., Diers, J., Fang, J., Ferguson, J., Ssewamala, F., Viner, R. M. (2016). Our future: a Lancet commission on adolescent health and wellbeing. The Lancet, 387(10036), 2423-2478. https://doi.org/10.1016/S01406736(16)00579-1

Rose-Clarke, K., Bentley, A., Marston, C., \& Prost, A. (2019). Peerfacilitated community-based interventions for adolescent health in low- and middle-income countries: A systematic review. PLoS One, 14(1), e0210468-e0210468.

http://dx.doi.org/10.1371/journal.pone.0210468

Somers, C. L., Wang, D., \& Piliawsky, M. (2016). Effectiveness of a Combined Tutoring and Mentoring Intervention With Ninth-Grade, Urban Black Adolescents AU - Somers, Cheryl L. Journal of Applied School Psychology, 32(3), 199-213.

http://dx.doi.org/10.1080/15377903.2015.1136719 
Twersky, F., Buchanan, P., \& Threlfall, V. (2013). Listening to those who matter most, the beneficiaries. Stanford Social Innovation Review, 11(2), 40-45.

https://ssir.org/articles/entry/listening_to_those_who_matter_most_th e_beneficiaries

UNESCO (2012). UNESCO Global Partnership for Girls' and Women 's Education - One Year On. UNESCO.

http://www.unesco.org/eri/cp/factsheets_ed/SN_EDFactSheet.pdf

World Bank. (2003). World Development Report 2004 : Making Services

Work for Poor People. The World Bank.

http://hdl.handle.net/10986/5986

Dr. Benta A. Abuya is a Research Scientist at the African Population and Health Research Center (APHRC) in Nairobi, Kenya.

Nelson Muhia is a Research Officer at the African Population and Health Research Center (APHRC).

Contact Address: Benta A. Abuya, African Population and Health Research Center (APHRC), APHRC Campus, Kirawa Road, off Peponi Road- P.O. Box 10787-00100. Nairobi, Kenya. Email: atienoa6@gmail.com or babuya@aphrc.org 